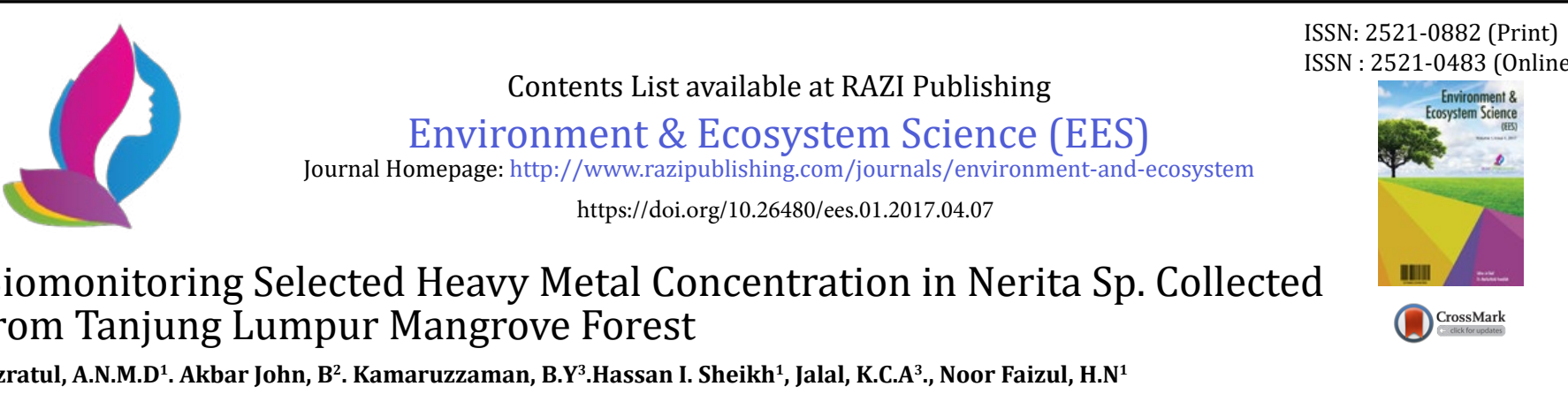

\title{
Biomonitoring Selected Heavy Metal Concentration in Nerita Sp. Collected from Tanjung Lumpur Mangrove Forest \\ Azratul, A.N.M.D ${ }^{1}$. Akbar John, B ${ }^{2}$. Kamaruzzaman, B.Y ${ }^{3}$.Hassan I. Sheikh ${ }^{1}$, Jalal, K.C.A ${ }^{3}$, , Noor Faizul, H.N ${ }^{1}$
}

${ }^{1}$ Department of Biotechnology, ${ }^{2}$ IINOCEM Research Station (IRS), ${ }^{3}$ Department of Marine Science, Kulliyyah of Science, International Islamic University Malaysia (IIUM), Kuantan, Pahang, , International Islamic University Malaysia (IIUM), Kuantan, Pahang.

This is an open access article distributed under the Creative Commons Attribution License, which permits unrestricted use, distribution, and reproduction in any medium, provided the original work is properly cited.

\section{ARTICLE DETAILS}

Article history:

Received 27 September 2016 Available online 10 January 2017

Keywords:

heavy metals, bio-monitoring, bioaccumulation, Nerita sp. Accepted 13 December 2016

\section{ABSTRACT}

Environmental pollution by heavy metals is a serious threat to human and ecosystem. Accumulation of heavy metals in the biota may pose hazardous impact on public health and other living organisms. By using gastropods Neritasp as bio-indicator, the levels of heavy metals in their soft tissues can determine the contamination of heavy metals in the Tanjung Lumpur Mangrove along the Kuantan River. The aim of this study is to identify copper cadmium, chromium and iron accumulated in the tissue of Neritasp, to investigate the concentration of the copper, cadmium, chromium and iron in the molluscan tissue among the different sizes of gastropod Neritaspand to compare the concentrations of heavy metals in a gastropod Neritasp tissue among the different stations of Kuantan River, Pahang. Gastropods of Neritasp were randomly collected along the river. The tissues of gastropods were digested with nitric acid. Then, concentration of copper, cadmium, chromium and iron were analyzed by using flame atomic absorption spectrophotometer (AAS) model Perkin Elmer SIMAA 6100 graphite furnace. Neritasp accumulate copper the most in their tissues compared to other heavy metals. The concentrations are around $189.8 \mu \mathrm{g} / \mathrm{L}-247.95 \mu \mathrm{g} / \mathrm{L}$. The highest concentration of copper is in Station 3 which is at $241.67 \mu \mathrm{g} / \mathrm{L}$. The second highest concentration is iron or ferrum where the concentrations are around $121.25 \mu \mathrm{g} / \mathrm{L}-174.55 \mu \mathrm{g} / \mathrm{L}$. Station 3 was identified to have the highest concentration of iron at $161.12 \mu \mathrm{g} / \mathrm{L}$. Followed by, chromium which the concentrations are around $23.49 \mu \mathrm{g} / \mathrm{L}-46.15 \mu \mathrm{g} / \mathrm{L}$. The highest concentration of chromium is Station 1 at 34.82 $\mu \mathrm{g} / \mathrm{L}$. The lowest concentration of heavy metals is cadmium which is around $8.69 \mu \mathrm{g} / \mathrm{L}-18.46 \mu \mathrm{g} / \mathrm{L}$. Also, Station 1 showed the highest concentration of cadmium at $17.56 \mu \mathrm{g} / \mathrm{L}$. This study can be used to identify contamination of heavy metals in marine zone by using bio-indicator to avoid environmental perturbation.

\section{INTRODUCTION}

Degradation of the marine environment occurs when nutrients, toxic chemicals and pathogens enter the environment and are present at levels greater than found naturally or result in adverse effects on the marine environment. Toxic compounds from industrial chemical, agriculture activities, mining activities and chemical released as a result of day-to-day port operations, TBT, an ingredients in antifouling paint used on the hulls of ships. The release of these metals into the coastal environment has the potential to impact significantly on humans and the wider environment. Once released, these metals cannot be broken down into safer compounds. There are many studies have been conducted and the scientists agreed that accumulation of heavy metals in the ecosystem is the main threat of environmental perturbation. Heavy metals are known as chemical elements with specific gravity that is at least 5 times the specific gravity of water which is 1 at 40C (390F). Heavy metals are considered as nondegradable elements, thus their persistence in the ecosystem will give detrimental effect to environment and living things. Examples of heavy metals that give harmful effect to human and environment are cadmium, lead, mercury, arsenic, copper, zinc and silver. Heavy metals are known to be a major anthropogenic contaminant of estuarine and coastal waters. Their inputs include urban run-off, industrial effluents, mining operations and atmospheric depositions and may be in particulate or dissolved forms. Although many are essential biological elements, all have the potential to be toxic to organisms above certain threshold concentrations, and for the protection of aquatic biota it is important that these limits not be exceeded in aquatic environments.

As part of investigation into heavy metals in the Kuantan River, Pahang, aquatic organisms, which are gastropods, had been chosen as a bioindicator to indicate the amount of heavy metals in this area. There are several reasons of choosing gastropod as a bioindicator. First, gastropods usually live in the area that are polluted, then they are sessile where this avoid gastropods to move away from the contaminated area, and because of that, the gastropods have to adapt in the polluted environment and show long term effects without being killed by the levels encountered in the environment.

Tanjung Lumpur is a traditional fishing village located near the mouth of the Kuantan River. This river provides source of food and a place for important infrastructure, transportation and industry. However, lots of constructions and developments have been done in this area. In addition, lots of boats and other vehicles use the river as a main way to move. Thus, there is a possibility of Kuantan River to be contaminated by certain heavy metals
In addition, according to Philips and Rainbow [1], sediment situated in the coastal area and estuaries accumulated the highest number of heavy metals. By utilizing bioindicator such as gastropods, the heavy metals in the tissue of the organisms can be determined and the investigation of heavy metals in soft tissue of mollusc is an important aspect of environmental pollution control.

Bioindicator are organisms that can be utilized to monitor the health of ecosystem form any pollution. These organisms have remarkable properties which they can bioaccumulate and biomagnify the pollutants like heavy metals, polycylic aromatic hydrocarbon and PCB in the environment in their tissues. Since these three decades, scientists and researchers used living organisms to indicate the areas that have potential to be contaminated. The main groups that are usually used to indicate pollution (bioindicator) are bacteria, algae, protozoa, invertebrates and fish

[2].

According to Nuenberg [3], mollusc had earlier been used as bioindicator of heavy metal pollution. Due to the reason, mollusc can accumulate higher concentration of metal ions than other groups of invertebrates [4]. Molluscs are highly sensitive to physical and chemical environmental stressor especially mollusc that live in marine ecosystem. Several studies indicate that molluscs can tolerate persistent toxic chemicals, such as metals, to a greater extent than other organisms and can serve as effective biomonitors or indicators [5].

Besides that, there are others special criteria of molluscs to act as ideal bioindicators. As prescribed by Philips [6, 7] and Langston and Spence [8] as below:

1. Ability to accumulate pollutants without being killed by the levels encountered in the environment.

2. Sedentary in order to be representative of the study area.

3. Sufficiently long-lived to allow the sampling of more than one year-class, if desired.

4. Be of reasonable size, giving adequate tissue for analysis.

5. Be easy to handle and identify, and hardy enough to survive in the laboratory to allow defecation before analysis (if desired) and laboratory studies of pollutant uptake.

6. Tolerate brackish water to allow transplantation.

7. The existence of a simple correlation between the pollutant content of the organism and the average pollutant concentration in the surrounding water. 
Thus, the present study was designed to have a comprehensive study on $\mathrm{Tg}$. Lumpur mangrove forest by analyzing physicochemical parameters of the water and metal accumulation in different size of Nerita sp. collected from different zones of sampling station.

\subsection{MATERIAL AND METHODS}

\subsection{Study Area}

Sampling was done in Kuantan River near the Tanjung Lumpur Mangrove area. There are three stations were chosen and the stations are plotted in Figure 1. The gastropods were collected in intertidal zone during low tide level. The GPS coordinates are given below (Table 1)

Table 1: Coordinate for each sampling stations along the Kuantan River

\begin{tabular}{|c|c|c|}
\hline Stations & I nngifı & | afitude \\
\hline 1 & $\mathrm{~N} \mathrm{CO}^{\circ} 48.34 \mathrm{~J}^{1}$ & $=103^{\circ} 20.066^{\prime}$ \\
\hline 2 & $\mathrm{~N} \mathrm{n} \cap 3^{\circ} \cdot 1831 \mathrm{~A}^{\prime}$ & $F 103^{\circ}>0051$ \\
\hline 3 & $\mathrm{~N} \mathrm{VO}^{\circ} 48.3^{\circ} 3^{\circ}$ & $=103^{\circ} .20 .040$ \\
\hline
\end{tabular}

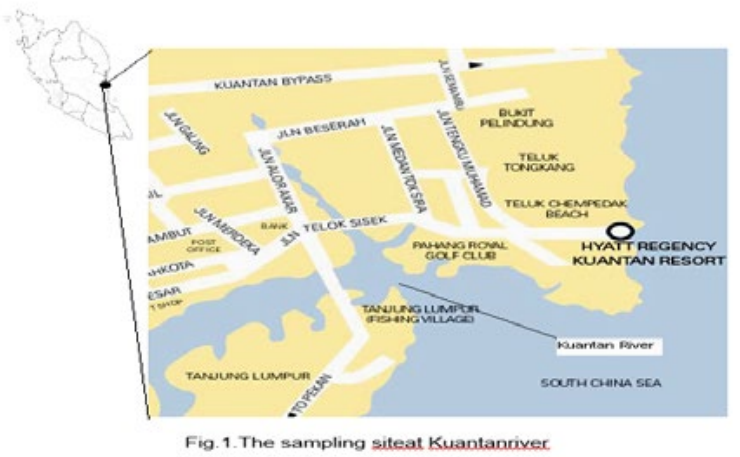

Three sampling stations were established along the Kuantan River. Sampling had been carried out in December 2007, 10. Gastropods of Neritasp samples were randomly collected by handpicking during low tide level at intertidal zone within the area of 5 meter radius for each station. GPS was used to identify the sampling location area. Besides that, the physiochemical parameters of water were also been measured such as temperature, $\mathrm{pH}$ total dissolved solid, salinity, dissolved oxygenand conductivity by using YSI - MPS 598. The collected organisms were kept in labeled plastic containers and packed in iced chest box and transferred to the laboratory for heavy metal analysis.

2.2 Sample collection and preparation

Nerita sp. were handpicked during low tide time and transported in ice condition to the laboratory. Distilled water was used to rinse and clean the samples of Nerita and were kept in freezer until analysis.

Specimens were pooled according to stations. Then, for each station, the samples were sorted to two sizes of groups of $1.00-2.00 \mathrm{~cm}$ (small) and $3.00-4.00 \mathrm{~cm}$ (large) of shell length. The shell lengths were recorded. The soft tissues of marine molluscs that had been collected were dissected with plastics forceps after breaking the shells with a hammer. After that, the soft tissues were put into the Petri dish. Then, the tissues were dried in an oven at $600 \mathrm{C}$ for 24 hours to obtain the constant weight. Finally, the dry weights of tissues were recorded.

\subsection{Wet Digestion}

Firstly, all of these procedures were performed inside the fume hood. About 3 gram of each sample was weighted (dry weight) into a Schott bottle. Then, the tissues were digested with $3 \mathrm{~mL}$ of trace metal HNO3 and 3 $\mathrm{mL}$ of $\mathrm{H} 2 \mathrm{~S} 04$ at room temperature for a night. The reaction was allowed to proceed. After a night, the bottles were placed in a hot plate and were heated at low temperature $(600 \mathrm{C})$ for 30 minutes. Then, the temperature was slightly increased to $1200 \mathrm{C}$. The tubes were removed when the samples went black, allowed to cool, then $1 \mathrm{~mL}$ of $\mathrm{H} 2 \mathrm{O} 2$ was added. The tubes were returned to the block and the $\mathrm{H} 2 \mathrm{O} 2$ addition was repeated until the samples were cleared. Lastly, the tubes were removed and made up to $30 \mathrm{~mL}$ with deionized water.

Blank was also analyzed following the same procedure as the digestion samples for calibration. In this method, trace metal nitric acid without samples is digested as per samples. This is done to make sure and to compare either there are any metal pollution occur or not. The reading obtained is needed to make sure that, there is no error caused by metals contamination or other chemical substances. The reading value from the test should be lower and to obtain good and accurate results, follows this formula Total concentration in samples $=$ Mean concentration in sample - Mean concentration blank

From the result obtained, the value was multiplied with 10 or 100 , according to the dilution factor used.

2.4 AAS analysis

Samples were transferred into a special tube and placed into the AAS machine and includes two blanks, one deionized water and one column for the furnace sample. Each sample was analyzed in triplicates by the machine. Next, different lamps was put in place in the graphite furnace AAS, SIMAA 6100 model by Perkin Elmer. Different lamps were placed for different element that needed to be analyzed. Argon is the gas used as the machines beam source. The calibration curve was drawn by the software by plotting the lead concentration $(\mu \mathrm{g} / \mathrm{L})$ versus the absorbance reading. The calibration curve is only accepted if the correlation coefficient $(r)$ is lesser than one and more than zero. A linear correlation coefficient is a number between -1 and 1 which measures how close this value is to zero, the less points fall along a line stretching from the lower left to the upper right. The value of $\mathrm{r}$ calculated for the calibration curve was 0.98591 , hence acceptable. Distilled deionised water was used as the blanks in all AAS runs. With every run of the machine analyzing the samples, one blank was also tested to ensure that the machine is working smoothly. The matrix modifier was placed in one of the 148 locations on the AAS plate. The machine was programmed to add $5 \mu \mathrm{L}$ of matrix modifier to the samples during each run. These included the samples and the blanks.

Table 2.Physiochemical parameters measured in the sampling site

\begin{tabular}{|l|l|l|l|l|}
\hline Stations & $\begin{array}{l}\text { Temperature } \\
\left({ }^{\circ} \mathrm{G}\right)\end{array}$ & $\begin{array}{l}\text { Salinity } \\
(\mathrm{DDt})\end{array}$ & $\begin{array}{l}\mathrm{DO} \\
(\mathrm{mg} / \mathrm{L})\end{array}$ & $\mathrm{PH}$ \\
\hline 1 & 26.31 & 10.45 & 3.04 & 6.55 \\
\hline 2 & 26.29 & 10.35 & 3.10 & 6.56 \\
\hline 3 & 26.33 & 10.42 & 3.05 & 6.60 \\
\hline
\end{tabular}

It has been observed that Neritaspaccumulated copper the most in their tissue compared to other heavy metals where the concentrations are around $189.8 \mu \mathrm{g} / \mathrm{L}-247.95 \mu \mathrm{g} / \mathrm{L}$. Station 3 gives the highest number of concentration of copper which is $247.95 \mu \mathrm{g} / \mathrm{L}$ (Table 3). The possibility of high copper concentration due to this station is near to the small jetty of fishing village of Tanjung Lumpur. The copper might come from the sewage effluent and disposal from the boats and others. The second highest concentration of heavy metals is Ferrum or also known as iron. The concentrations are around $121.25 \mu \mathrm{g} / \mathrm{L}-174.55 \mu \mathrm{g} / \mathrm{L}$. The highest concentration is discovered in Station 3. Iron can be found naturally in minerals, rocks, soils and it is essential to living organisms. Iron can be added to environment by using it in steels and other alloys.

Cadmium also had been analyzed in the tissue of the gastropods. The concentrations are around $8.69 \mu \mathrm{g} / \mathrm{L}-18.46 \mu \mathrm{g} / \mathrm{L}$. Station 1 has the highest concentration of cadmium. The reason is that this station is near to main road where vehicles like motors, cars, buses and trucks use the road as their daily way. This could cause oil spill, leakage or chemical from the car batteries flow into this area and consumed by Nerita sp. Besides that chromium had also been evaluated. The concentrations are around 23.49 $\mu \mathrm{g} / \mathrm{L}-46.15 \mu \mathrm{g} / \mathrm{L}$. The highest concentration is also found in

Station 1. Chromium might be released from the steels and car parts that plated with chromium.

Table 3.Concentration of Copper, Cadmium, Chromium and Ferrum in analyzed tissues of Neritasp in Three Stations along the Kuantan River.

\begin{tabular}{|l|l|l|l|l|l|}
\hline \multirow{2}{*}{ Stations } & \multirow{2}{*}{ Size $(\mathrm{cm})$} & \multicolumn{4}{|l|}{ Concentration of Heany Metals $(\mu \mathrm{\mu g} / \mathrm{L})$} \\
\cline { 3 - 6 } & & Cu & \multicolumn{1}{l|}{} \\
\hline \multirow{2}{*}{ Station 1 } & Large $(3.00-4.00)$ & 232.1 & 18.46 & 46.15 & 150.4 \\
\cline { 2 - 6 } & Small $(1.00-2.00)$ & 224.45 & 16.65 & 23.49 & 121.25 \\
\hline \multirow{2}{*}{ Station 2 } & Large $(3.00-4.00)$ & 226.18 & 16.28 & 33.48 & 144.48 \\
\cline { 2 - 6 } & Small $(1.00-2.00)$ & 189.8 & 8.69 & 32.6 & 131.1 \\
\hline \multirow{2}{*}{ Station 3 } & Large $(3.00-4.00)$ & 247.95 & 15.65 & 34.1 & 174.55 \\
\cline { 2 - 6 } & Small $(1.00-2.00)$ & 235.39 & 6.09 & 25.75 & 147.69 \\
\hline
\end{tabular}

Station 3 has the highest mean concentration of copper around $241.67 \mu \mathrm{g} / \mathrm{L}$. While the lowest mean concentration of copper is Station 2 which is around $207.99 \mu \mathrm{g} / \mathrm{L}$ (Fig 2). For cadmium element, the highest mean concentration is Station 1, which is at $17.56 \mu \mathrm{g} / \mathrm{L}$. Followed by, Station 2 which gives the lowest mean concentration at $12.49 \mu \mathrm{g} / \mathrm{L}$ (Fig 3). For chromium, the highest mean concentration is identified in Station 1, which is at $34.82 \mu \mathrm{g} /$ L. Compared to Station 3, it has the lowest of chromium concentration at $29.93 \mu \mathrm{g} / \mathrm{L}$ (Fig 4). In addition, ferrum is also found and Station 3 gives the 
highest mean concentration around $161.12 \mu \mathrm{g} / \mathrm{L}$. Whereas, Station 1 has the lowest mean concentration at $135.83 \mu \mathrm{g} / \mathrm{L}$ (FIG 5).
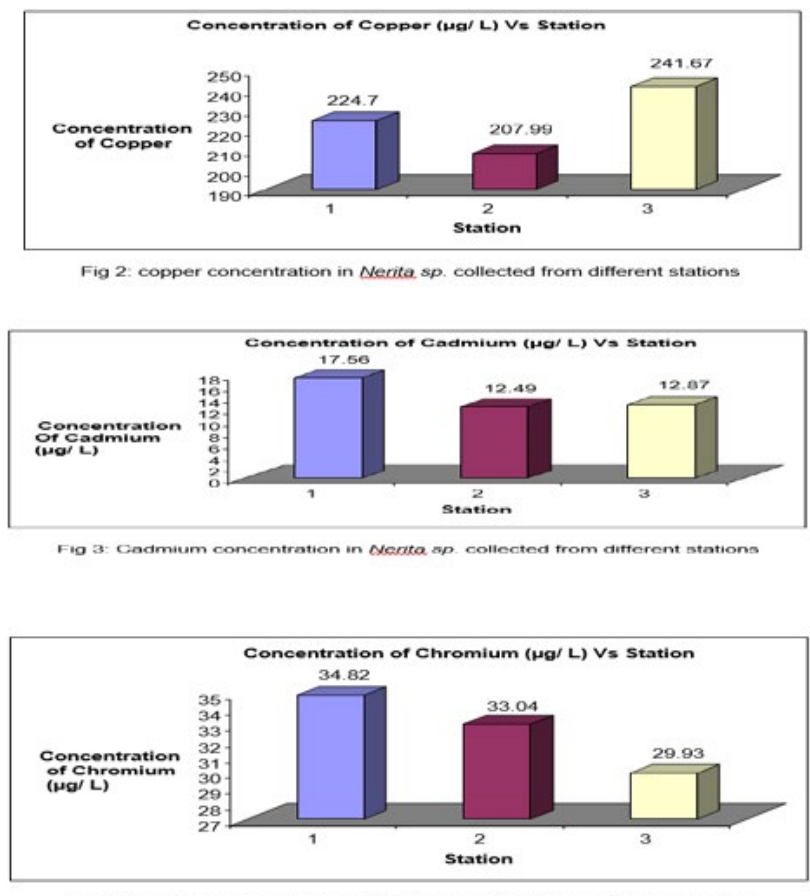

Fig 4: Chromium concentration in Nerita sp. collected from different stations

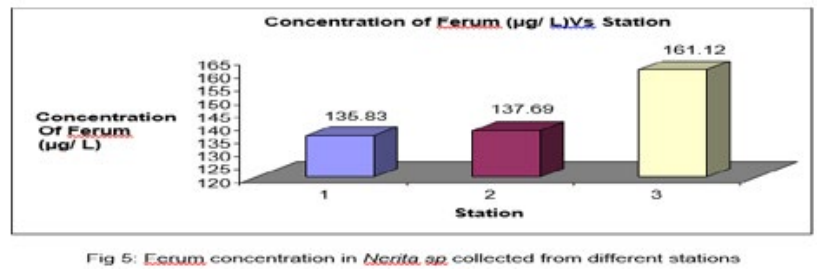

It was observed that the accumulation of $\mathrm{Cu}$ within different size of gastropods in the Three Stations give strong positive relationship which R2 $>0.50$. These results show that the concentration of copper increasing with the increasing of size of the gastropods. There are also very strong positive relationships between the size of the gastropods and the concentration of Cd was observed. These show that the concentration of cadmium increasing with increasing of size of the gastropods. It was also showed a strong positive relationship between the size and the concentration of $\mathrm{Cr}$ in the tissues of the gastropods. These are shown in every station where the R2> 0.50 . Thus, chromium concentration increases with the increases size of the gastropods. Overall, all of the elements which are copper, cadmium, chromium and ferrum, they give positive linear relationships where all of these elements concentration are increasing with the increasing the size of the body of the gastropods.

\subsection{DISCUSSION}

\subsection{Concentration of Copper}

From the results, it was found that the highest mean concentration of heavy metals was copper $(\mathrm{Cu})$ that present in the tissues of gastropods. Copper is an element that essential to living organisms and humans. Copper is found in the variety of enzymes including the copper centers of cytochrome c oxidase and the enzyme superoxidase dismutase. In addition to its enzymatic roles, copper is used for biological electron transport. However, if the level is extended to a requirement level, copper might bring unhealthy condition to organisms and environments where the binding of excess copper to specific protein sites can disrupt several metabolic processes. In the gastropods, copper is required for typical haemocyanin load for oxygen transport [9].

The external factor that might influence the concentration rate of copper in the gastropods when the copper is absorbed from the alloyed with nickel, for instance, cupronickel that is used as corrosive assistant materials in shipbuilding and boats. Thus, Station 3 gives the highest value of copper which near to small jetty. As a result, Neritasp can be applied as a bioindicator because they can indicate pollution at different rate and level.

\subsection{Concentration of Ferrum}

The second abundant pollutant in Neritasp is iron. The highest concentration was identified in Station 3 at $161.12 \mu \mathrm{g} / \mathrm{L}$. Iron is also essential to nearly all known organisms with concentration approximately $0.02 \%$. It is a very essential element for oxygen exchange and oxidizing process. There are studies reported that deficiency of iron may leads to anaemia but excess iron in the body causes liver and kidney damage [10]. There are several reasons why iron had been among the highest concentration of heavy metal. In the area where the studies was done, iron might come from the steels and alloys that used in countless products. It was also found in the studied area where so many iron-based products such as pipes, pieces of roof that made of galvanized iron sheet and other products were thrown away along the Kuantan River. In this way, iron has been spread away and reached soil and water, as a consequence, it is taken up by Neritaspand thus enter food chain. In addition, due to its essential property, iron may be found in very high concentrations in the body of organisms, which incorporated in blood pigments. Thus, this reason will affect the reading of iron concentration in the tissues of gastropods. Neritasp is suitable to be used as a bioindicator for iron along the Kuantan River because they are showed differences in accumulation of iron in each station.

\subsection{Concentration of Chromium}

The third highest concentration of heavy metals in the Three Stations is Chromium. Station 1 was found to be the highest concentration of chromium at $34.82 \mu \mathrm{g} / \mathrm{L}$. Chromium is known as non-essential element to living organisms. Therefore, it has no beneficial effects on human body. The targets of organs are eyes, skin and respiratory system [10].The chromium contamination might be occurred from the human activities in the area of study. Chromium had been used in extensive practices such as plating car parts, tools, camouflage paint and other applications. Moreover, chromium is added to steel to harden it and to form stainless steel, which steel alloy that contains at least $10 \%$ chromium. Due to this reason, Station 1 has the highest chromium concentration where this station is near to roadways. There were plentiful of car parts and stainless steels were found in this station. There is a possibility human threw these components to this site. Chromium that enters the marine ecosystem will contaminate the water and accumulated by marine organisms, thus give deleterious effects on human and environment. That is why Neritasp had been chosen to indicate the chromium contamination in Tanjung Lumpur Mangrove along the Kuantan River.

\subsection{Concentration of Cadmium}

From all of the four heavy metals, cadmium seems to be the lowest among all but the concentration is still at the high rate and polluted the area of study. The highest concentration of cadmium was identified at Station 1, which is at $17.56 \mu \mathrm{g} / \mathrm{L}$. Cadmium is also a non-essential metal and it has no constructive purpose in the human body. Their compounds are extremely toxic even in low concentration. They will give negative impact if accumulated in organisms and severe destructive of ecosystem [11].Cadmium has a wide variety of sources in the environment and from industry. There are several reasons about the possibility of cadmium contamination in the investigated area. Cadmium might be released from the intentional use of fertilizer from the agricultural products. This metal will be accumulated in soils and become exposed to run-offs during rainy season. Besides that, cadmium is also a constituent of alloys, pigments, batteries, metal coatings such as protective coating on steels and plastics. Cadmium is also found in fumes from the vehicles. Thus, as of these rationales, Station 1 was more exposed to cadmium pollution because this area is near to roadway where many vehicles pass and use it as their daily route. Moreover, a lot of plastic garbage and steels were found. Hence, Neritasp had been utilized to show the level of cadmium contamination in each Three Stations.

As metals are non-biodegradable and once introduced into the aquatic environment, these pollutants will undergo a variety of interactions, which may lead to their activation or more probably to detoxification. The fate of chemicals is mainly influenced by their stability. Stable compounds may persist for a long time in the environment but in terms of acute toxicity, they are not so toxic. However, for less stable compounds, they can change into more toxic forms or bind to biological molecules within organisms thus causing damage.

Heavy metals that released can be distributed among several different forms within the water environment. Metals can be either transported with the water and suspended sediment or stored within the riverbed bottom sediments. Heavy metals are transported as:

(1) Dissolved species in the water

(2) Suspended insoluble chemical solids

(3) Components of the suspended natural sediments

Metals dissolved in the water can exist as hydrated metal ions or as aqueous metal complexes with other organic or inorganic constituents. Both inorganic and organic solids can be transported with the water as individual entities or as chemical coatings on suspended sediments. In addition, mineral components of suspended sediments themselves can contain heavy metals. Heavy-metal solids can also be stored in river-bottom sediments. Thus, these metals have the potency to bioaccumulate inside the body of organisms that lived within the sediment or river such as fishes and marine 
molluscs. Once human consumed, heavy metals become toxic when they are not metabolized by the body and accumulate in the soft tissues, therefore, they will persist long inside the body. As a result, severe damage effect to human body.

The regression analysis established presented in Chapter III, showed that tissue metal concentrations were dependent of mass for Neritaspfor all the metals examined. It has also been postulated by Catsiki [12], where there are several factors which influencing the accumulation of heavy metals in the tissue of organisms. One of them is the size of organisms where the result chapter presented that large size contains high level of heavy metal or small size contains low level of heavy metals. These occurrences are called size dependent metal concentrations.

It was pointed out that since the early 1970's [13] that the size of shellfish shows a better correlation with their heavy metal concentration. Moreover, the body size is considered as a major biological factor influencing metal concentrations of specimens collected at the same locality [14]. From the analysis done, all of the stations showed that concentration of heavy metal levels are higher in the larger organisms or vice versa. According to Bayne [15], if more tissues or high number of tissues in the body of an organism, it will produce more gametes. Thus, larger individuals will show more fertility and higher percentage of gametes weight. Therefore, larger animals can dilute more heavy metals compared to smaller individuals These phenomena elucidate the linear relationship between size and the concentration of heavy metals, which had been shown in the regression test of the chapter of the result.

Copper, cadmium, chromium and ferrum, they showed positive regression relationship between the concentrations of heavy metals and size of Neritasp, which describe that, the concentration of heavy metals increasing with the size of the gastropods. In addition, the changes of metabolic rates of bivalves with length and season as well as the variation in bioavailability of metals in the surrounding with time might be responsible for these to occur in these molluscs $[16,17]$. In simple words, the longer the time, the more heavy metals they can absorb and accumulate in their tissues. Moreover, according to Philips and Rainbow [1], the mass dependent in tissue metal concentration may be due to some form of regulation of uptake and excretion. There is a possibility where the excretions by the organisms are not balance with the intake of the heavy metals. Marine invertebrates accumulate heavy metals depend on the availability of intake, excretion and dilution rate of heavy metals. Hence, there are increasing of heavy metals with the size and age of the gastropods. However, for the smaller specimens, they are young and may have absorbed lower metal concentration due to less exposed or as a result of dilution rapid growth [18]. In addition, PaezOsuna and Ruiz-Fernandez [19] explained that the observed lower heavy metals concentration in the small gastropods might be attributed to lower metabolic rate of this species. Then, the lower surfaces to volume ratio in the smaller mean that there is a relatively smaller surface uptake of metals if they are taken directly from the water. It is also possible that some dietary changes occur as the individuals grow.

From the analysis done, Neritasp that were collected along the Kuantan River, this invertebrates accumulated all of the heavy metals show strong positive regression with size of the organisms. This is because the potential of Neritasp to satisfy most of the basic requirements specified by Philips [7] for effective biomonitor, they are:

1. Sedentary and therefore representative of the study site

2. Hardy and tolerant of high levels of heavy metals and salinity

3. Abundant in coastal and estuarine environments

4. Easy to identify, collect and provide sufficient tissue for analysis of trace metal concentrations

Furthermore, gastropods have been used for metal analysis because they provide a time integrated indication of environmental contamination. In comparison to fish and crustaceans, gastropods have a very low level of activity of enzyme systems capable of metabolizing persistent organic pollutants such as aromatic hydrocarbons and polychlorinated biphenyls. Therefore, contaminants concentration in the tissues of mollusc were more accurately reflect the magnitude of environmental contamination [7]. For this reason, Neritasp were chosen to act as potential bioindicator at Kuantan River for heavy metals analysis due to the reason where the accumulation of copper, cadmium, chromium and iron showed positive regression with size of the organisms. Accumulation of metals is higher in older or larger Nerita sp.

In conclusion, Neritasp has the criteria to be the potential bioindicator to point out pollution that occurs in the area of Tanjung Lumpur Mangrove along the Kuantan River. Due to the reason, this area had been exposed to variety of pollutants and contaminants like heavy metals. Therefore, this study is hoped to advocate environmental surveillance of this area in order to achieve good ecosystem quality and contaminant-free area for safe human health.

\subsection{REFERENCES}

[1] D. J. H. Phillips, P. S. Rainbow, Biomonitoring of Trace Aquatic Contaminants, Elsevier Sci. Publ., Barking, 1994.

[2] B. A. Whitton, River Ecology, Blackwell Scientific Publication, Springer, Verlag Berlin Heidberg. 1975, pp. 3-321.

[3] H. W. Nuernbarg, Bio-accumulation of Heavy Metals by Bivalves from Limfford (North Adriatic Sea), Journal of Marine Biological Sciences 81(2) (1984), 177-180.

[4] A. Beaby, S. L. Eaves, Short Term Changes in $\mathrm{Pb}, \mathrm{Zn}$ and $\mathrm{Cd}$ Concentrations of The Garden Snail Helix aspersa(Muller) from a Central London Car Park, Environmental Pollution (series A), 30 (1983), 233-244.

[5] R. Smolders, L. Bervoets, V. Wepener, R. Blust, A Conceptual Framework for Using Mussels as Biomonitors in Whole Effluent Toxicity, Hum. Ecol. Risk Assess. 9(3) (2003), 741-760.

[6] D. J. H. Philips, Quantitative Aquatic Biological Indicators. Applied Science Publisher Ltd., 1980, p. 411.

[7] D. J. H. Phillips, The Use of Macroalgae and Invertebrates as Monitors of Metal Levels in Estuaries and Coastal Waters, CRC Press, Boca Raton, 1990.

[8] W. J. Langston, S. K. Spence, Metal Analysis, in: P. Calow (Ed), Handbook of Ecotoxicology, Blackwell Scientific, Oxford, UK. 1994, pp. 4578.

[9] J. E. J. Weckx, H. M. M. Clijsters, Zn phytotoxicity induces oxidative stress in primary leaves of Phaseolus vulgaris, Plant Physiology and Biochemistry 35.5 (1997), 405-410.

[10] K. Barbalace, Periodic Table of Elements - Cadmium, Iron, Chromium Environmental Chemistry.com, 2008, Available from http:// EnvironmentalChemistry.com/yogi/periodic-/Cd.html.

[11] M. Shannon, Heavy Metal Poisoning, in: L. M. Haddad, M. Shannon, J. F. Winchester (Eds.), Clinical Management of Poisoning and Drug Overdose, Third Edition, Saunders, US. 1998.

[12] V. A. Catsiki, A. Mylona, N. Mimikos, The Impact of Size on the Bioaccumulation Rate of Heavy metals and PARs by Mytilusgalloprovincialisfrom Saronikos gulf, UNEP MAP Techn. Report Series No 59 (1991), 153-161.

[13] J. Peden, J. H. Crothers, C. E. Waterfall, J. Beasley. Heavy Metals in Somerset Marine Organisms, Mar. Pollut. Bull. 4 (1) (1973), 7-9.

[14] C. Nolan, Trace Metal Accumulation in Molluscs: The effects of variables and variability on sampling strategies. MAP technical reports series. Athens [MAP TECH. REP. SER.] Series No 59:259-278, 1991.

[15] B. L. Bayne, Marine Mussels: Their Ecology and Physiology, Cambridge University Press, Cambridge. 1976, p. 506.

[16] C. R. Boyden, Trace Element Content and Body Size in Molluscs, Nature 251 (1974), 311-314.

[17] D. Cossa, J. G. Rondeau, Seasonal, Geographical and Size Induced Variability in Mercury Content of Mytilusedulisin an Estuarine Environment: A Re-assessment of Mercury Pollution Level in the Estuary and Gulf of St. Lawreence, Mar. Biol. 88 (1985), 43-49.

[18] K. M. Y. Leung, I. J. Morgan, R. S. S. Wu, T. C. Lau, J. Svavarsson, R. W. Furness, Growth Rate as a Factor Confounding the Use of The Dogwhelk Nucella lapillus as Biomonitor of Heavy Metal Contamination, Marine Ecology-Progress Series. 221 (2001), 145-159.

[19] F. Paez-Osuna, C. Ruiz-Fernandez, Trace metals in the Mexican shrimp Penaeus vannamei from estuarine and marine environments, Environmental Pollution, 87(2) (1995), 243-247. 